\title{
IDIOM BAHASA JEPANG YANG TERBENTUK DARI KATA NEKO
}

\author{
A. Amalia ${ }^{1}$, Hartati ${ }^{2}$, Y. Suryadi ${ }^{3}$ \\ ${ }^{123}$ Sastra Jepang, Universitas Jenderal Soedirman, Purwokerto \\ e-mail: adlinaamalia20@gmail.com, hartati@unsoed.ac.id, yudi.suryadi@unsoed.ac.id
}

\begin{abstract}
Abstrak
Penelitian berjudul Idiom Bahasa Jepang yang terbentuk dari kata Neko. Penelitian ini bertujuan untuk 1) memaparkan apa saja idiom yang terbentuk dari kata neko 'kucing', 2) menjelaskan makna leksikal dan idiomatikal idiom yang terbentuk dari kata neko 'kucing'. Penelitian ini dilakukan dengan menerapkan metode deskriptif kualitatif. Data dari penelitian ini dikumpulkan dengan menggunakan teknik simak catat. Data dalam penelitian ini berupa idiom bahasa Jepang yang terbentuk dari kata neko. Sumber data dalam penelitian ini adalah laman yourei.jp dan aozora.gr.jp. Berdasarkan dari hasil analisis, terdapat 21 idiom yang terbentuk dari kata neko 'kucing', dan terdiri dari 6 idiom neko berdasarkan makna yang berhubungan dengan emosi dan perasaan, 4 idiom neko berdasarkan makna yang berhubungan dengan tubuh, watak, dan sikap, 7 idiom neko berdasarkan makna yang berhubungan dengan perbuatan, aksi, dan aktivitas, serta 4 idiom neko yang berhubungan dengan keadaan, derajat, dan nilai.
\end{abstract}

Kata kunci: idiom, kanyōku, makna idiom, idiom yang terbentuk dari kata neko

\section{Abstract}

The research entitled Japanese Idioms using the Word Neko. Aims to 1) describe what are the Japanese idioms using the word neko 'cat' 2) explain the lexical and idiomatical meaning of Japanese idioms using the word neko 'cat'. This research was conducted by applying the descripive qualitative method. The data of this research are obtained by using reading and note taking technique. The data of this research is Japanese idioms using the word neko. The data sources of this research are aozora.gr.jp and yourei.jp. The result of the analysis shows that there are 21 Japanese idioms using the word neko, consists of 6 neko idioms based on meanings related to emotions and feelings, 4 neko idioms based on meanings related to the body, character, and attitude, 7 neko idioms based on meangings related to the act, action, and activity, 4 neko idioms based on meanings related to state, degree, and value.

Keywords : idioms, kanyōku, idiomatic meanings, idiom using the word neko

\section{Pendahuluan}

Bahasa adalah alat komunikasi antara anggota masyarakat, berupa simbol bunyi yang dihasilkan oleh alat ucap manusia. Bahasa juga dapat diartikan sebagai alat untuk menyampaikan sesuatu yang terlintas di dalam hati, bahasa sebagai alat untuk berinteraksi atau alat untuk berkomunikasi. Sebagai alat komunikasi manusia, bahasa adalah suatu sistem yang bersifat sistematis dan sekaligus sistemis. Sistemis memiliki arti bahwa bahasa itu bukan suatu sistem tunggal, melainkan terdiri pula dari beberapa subsistem, yaitu subsistem fonologi, subsistem morfologi, subsistem sintaksis, dan subsistem semantik, kajian ini merupakan pula cabang dari linguistik (Chaer, 2003:4). Oleh karena itu, selain sebagai alat untuk berkomunikasi, idiom, peribahasa, dan kosakata merupakan hal yang patut untuk dipahami karena itu perlu bagi kita untuk mempelajari bahasa.

Menurut Martinet dalam Chaer (2003:6) linguistik adalah ilmu yang mengambil bahasa sebagai objek kajiannya dan merupakan telaah ilmiah dalam bahasa manusia. Linguistik sebagai ilmu harus memiliki sistem pada setiap gejala yang dimilikinya, seperti sistem bunyi bahasa (fonem), sistem bentuk bahasa (morfem), sistem kalimat (sintaksis), dan kajian makna (semantik). Semantik menurut Tarigan (dalam Suhardi, 2015:17) merupakan ilmu tentang tanda. Semantik menelaah lambang-lambang atau tanda-tanda 
yang menyatakan makna, hubungan makna yang satu dengan makna lain, dan pengaruhnya terhadap manusia dan masyarakat. Menurut Sutedi (2011:127) semantik memegang peran penting, karena selain digunakan dalam berkomunikasi juga digunakan untuk menyampaikan makna. Misalnya, ketika seseorang menyampaikan ide kepada lawan bicaranya, pemahaman yang didapat oleh lawan bicara merupakan tanda bahwa lawan bicara dapat menyerap makna yang disampaikannya. Begitu juga dengan idiom, maksud dari idiom akan tersampaikan apabila kita dapat menyerap dan mengerti maknanya. Oleh karena itu, idiom merupakan salah satu kajian semantik yang perlu diteliti dan dipelajari.

Idiom menurut Chaer (2003:296) merupakan ujaran yang tidak dapat diramalkan dari makna unsur-unsur pembentuknya, baik secara leksikal maupun gramatikal. Menurut Keraf (2006:109) idiom adalah pola-pola struktural yang menyimpang dari kaidah-kaidah bahasa yang umum, biasanya berbentuk frasa, klausa, sedangkan artinya tidak bisa diterangkan secara logis atau secara gramatikal, dengan bertumpu pada makna kata-kata yang membentuknya. Idiom dalam bahasa Jepang diartikan sebagai kanyōku (慣用句) yaitu ungkapan yang terbentuk dari beberapa kata yang makna secara keseluruhannya bukan merupakan penjumlahan makna unsur-unsur pembentuknya (Miharu, 2000:47). Ungkapan atau idiom dapat diartikan sebagai ekspresi kebahasaan yang digunakan oleh penutur untuk menyampaikan pikiran, perasaan, dan emosinya dalam bentuk -bentuk satuan tertentu yang dianggap paling tepat dan paling kena (Chaer, 1994:9).

Idiom dalam bahasa Jepang juga ada bermacam-macam, Menurut Sutedi (2011:9697), apabila dilihat dari strukturnya, kanyōku terdiri dari empat tipe, yaitu: (1) tidak bisa diselipi apapun; (2) tidak bisa berubah posisi (menjadi suatu modifikator); (3) tidak bisa diganti dengan kata yang lain (sinonim atau antonim); dan (4) ada yang hanya dalam bentuk menyangkal saja dan tidak bisa diubah ke dalam bentuk positif.

Menurut Chaer (2003:296) bentuk idiom dibagi menjadi 2 yaitu sebagai berikut.

\section{(1) Idiom Penuh}

Idiom penuh adalah idiom yang semua unsur-unsurnya sudah melebur menjadi satu kesatuan, sehingga makna yang dimiliki berasal dari seluruh kesatuan itu. Bentuk-bentuk idiom seperti membanting tulang, menjual gigi, dan meja hijau termasuk idiom penuh, karena jika dipisahkan tidak memiliki makna idiomatikal dan tidak mempunyai makna leksikal didalamnya (Chaer, 2003:296).

Idiom penuh dalam bahasa Jepang contohnya adalah yang terdapat dalam klausa ude ga naru yang secara idiomatikal bermakna 'bersemangat' dan tidak bisa dimaknai secara leksikal, karena jika secara leksikal berarti 'lengan berbunyi' sama halnya dengan idiom hara ga tatsu yang bermakna idiomatikal 'marah' secara leksikal berarti 'perut berdiri' yang mana tidak memiliki keterkaitan antara makna idiomatikal dan leksikal dan hanya dapat dimaknai secara idiomatikal saja, karena jika diterjemahkan secara leksikal kalimat tersebut tentu menjadi janggal (Sutedi, 2011:176).

(2) Idiom Sebagian

Idiom sebagian adalah idiom yang salah satu unsurnya masih memiliki makna leksikalnya sendiri. Misalnya, buku putih yang bermakna idiomatikal 'buku yang memuat keterangan resmi mengenai suatu kasus' mempunyai makna leksikal; daftar hitam yang bermakna 'daftar yang memuat nama-nama orang yang diduga atau dicurigai berbuat kejahatan'; dan koran kuning dengan makna 'koran yang biasa membuat berita sensasi'. Ketiga contoh tersebut mempunyai makna leksikal dan idiomatikal oleh karena itu disebut idiom sebagian (Chaer, 2003:296).

Idiom sebagian dalam bahasa Jepang contohnya adalah klausa pada idiom ashi o arau yang memiliki dua makna, yaitu secara leksikal bermakna 'mencuci kaki' dan secara idiomatik bermakna 'menghentikan perbuatan buruk/bertaubat' (Sutedi, 2011:176).

Klasifikasi idiom menurut Inoue Muneo (1992:4-10) adalah sebagai berikut.

1）感覚、感情を表す慣用句

Kankaku, kanjō o arawasu kanyōku

Idiom yang menunjukkan perasaan dan emosi 
2） からだ、性格、態度を表す慣用句

Karada, seikaku, taido o arawasu kanyōku

Idiom yang berhubungan dengan tubuh, watak, dan sikap

3) 行為、動作、行動を表す慣用句

Kōi, dōsa, kōdo o arawasu kanyōku

Idiom yang menunjukkan perbuatan, aksi, dan aktivitas

4) 状態、程度、価值を表す慣用句

Jōtai, teido, kachi o arawasu kanyōku

Idiom yang menunjukkan suatu keadaan, derajat, dan nilai

5）社会、文化、生活を表す慣用句

Shakai, bunka, seikatsu o arawasu kanyōku

Idiom yang menunjukkan masyarakat, budaya, dan kehidupan

Idiom selain digunakan untuk mengungkapkan ekspresi seseorang dalam meyampaikan pikiran, perasaan, dan emosi juga merupakan wadah atau sarana untuk memperhalus perkataan dan kalimat sehingga lawan bicara tidak tersinggung dengan perkataan pembicara, idiom dalam bahasa Jepang mempunyai banyak fungsi, seperti untuk memuji, meninggikan, dan yang paling utama adalah untuk menjaga perasaan lawan bicara dengan tidak secara langsung menyampaikan hal yang ingin diucapkan atau ditulisakan melainkan menyampaikannya secara idiomatikal atau ungkapan yang maknanya bersifat tidak langsung. Banyak jenis idiom yang digunakan oleh masyarakat Jepang, diantaranya adalah idiom yang menggunakan anggota tubuh, tumbuhan, alam, hewan dan lain-lain. Objek idiom yang akan dibahas oleh penulis dalam penelitian ini adalah objek hewan berkaki empat, kucing.

Kucing merupakan binatang yang sudah hidup berdampingan dengan masyarakat Jepang sejak dulu, karena sangat dihormati dan dipercaya dapat memberikan keberuntungan. Masyarakat Jepang mengaplikasikan bentuk kecintaan mereka terhadap kucing melalui berbagai karya seni, seperti patung, lukisan, novel, film, anime, bahkan di Jepang terdapat 13 pulau kucing yakni di pulau Tashirojima, pulau Enoshima, pulau Okishima, pulau Sanagishima, pulau Manabeshima, pulau Ogijima, dan lain-lain. Di Jepang juga terdapat hari kucing yakni pada tanggal 22 Februari. Melalui hal-hal tersebut dapat dilihat bahwa masyarakat Jepang menganggap kucing sebagai binatang yang spesial dan bahkan menghormatinya. Berdasarkan hal tersebut, penelitian ini penting dilakukan untuk mengetahui idiom-idiom bahasa Jepang yang terbentuk dari kata kucing yang memiliki peran penting dalam kehidupan masyarakat Jepang.

\section{Metode}

Penelitian ini merupakan penelitian deskriptif kualitatif, yakni mendeskripsikan data berupa idiom yang terbentuk dari kata neko, kemudian menganalisis makna leksikal dan idiomatikalnya. Data yang digunakan dalam penelitian ini berupa kalimat yang mengandung idiom neko. Sumber data yang digunakan pada penelitian ini adalah laman aozora.gr.jp dan yourei.jp. Sumber data tersebut dipilih karena banyak menampilkan data berupa kalimat yang didalamnya mengandung idiom neko. Teknik pengumpulan yang digunakan dalam penelitian ini adalah teknik simak. Metode simak merupakan cara yang dilakukan untuk memperoleh data yang dilakukan dengan menyimak bahasa (Mahsun, 2007:92). Istilah menyimak yang digunakan pada penelitian ini adalah menyimak bahasa secara tertulis. Setelah semua data terkumpul, penulis menyortir data tersebut serta menerjemahkannya.. 


\title{
3. Hasil dan Pembahasan
}

Data berupa penggalan kalimat yang diperoleh dari laman aozora.gr.id dan yourei.jp. Melalui hasil analisis yang telah dilakukan, terdapat 21 idiom bahasa Jepang yang terbentuk dari kata neko dan dibagi berdasarkan klasifikasi makna idiom menurut Muneo.

\section{Berdasarkan Makna yang Berhubungan dengan Perasaan dan Emosi}

\author{
(1) 猫 の 魚辞退 \\ Neko no uojitai \\ Kucing menolak ikan \\ $\mathrm{N} \quad \mathrm{P} \quad \mathrm{N}$
}

Idiom neko no uojitai berdasarkan pembentuknya terbentuk dari nomina neko 'kucing', partikel no dan nomina uojitai 'menolak ikan', sehingga arti idiom ini secara leksikal berarti 'kucing yang menolak ikan'. Namun secara idiomatikal neko no uojitai merupakan sebuah ungkapan untuk seseorang yang sebenarnya sangat menginginkan suatu hal tapi malah menolaknya dengan keras. Dapat dilihat dari contoh kalimat pada tuturan sebagai berikut.
まきこ：ねえ、あなた。うちの子ったら、この前のテストの成績があんまりにも悪かっ たから、当分はお小遣いはいりませんですって。
とおる:猫の魚辞退ってね、いつまで続くことやら
Makiko : nee, anata. Uchi no ko ttara, kono mae no tesuto no seiseki ga anmari ni mo warukattakara, toubun wa okodzukai wa irimasen desutte.
Tooru : neko no uojitai tte ne, itsumade tsudzuku koto yara
Makiko : 'hei.. sayang, kata anak kita, dia tidak butuh uang saku, karena ujian kemarin hasilnya tidak terlalu bagus'
Tooru : ' 'padahal sebenarnya mau ya, kita lihat sampai kapan ini akan berlangsung.'

(aozora.gr.jp)

Pada contoh kalimat diatas menggambarkan kedua orangtua yang sedang membicarakan anaknya yang tidak lagi menginginkan uang saku karena nilai ujiannya yang tidak bagus, tapi ayahnya yang sudah mengetahui sifat anaknya berfikir bahwa hal itu tidak aka berlangsung lama, alias walaupun berkata tidak mau di awal pasti pada akhirnya anak mereka tetap akan meminta uang saku. Menurut Nishikawa (2017:113) idiom neko no uojitai merupakan ungkapan untuk seseorang yang sangat menginginkan suatu hal tapi malah menolaknya mati-matian, tapi hal tersebut tidak hanya sementara, seperti kucing yang menolak makanan favoritnya, ikan, walaupun mereka menolak, pasti pada akhirnya kucing akan tetap memakan ikan. Karena itu muncullah idiom neko no uojitai.

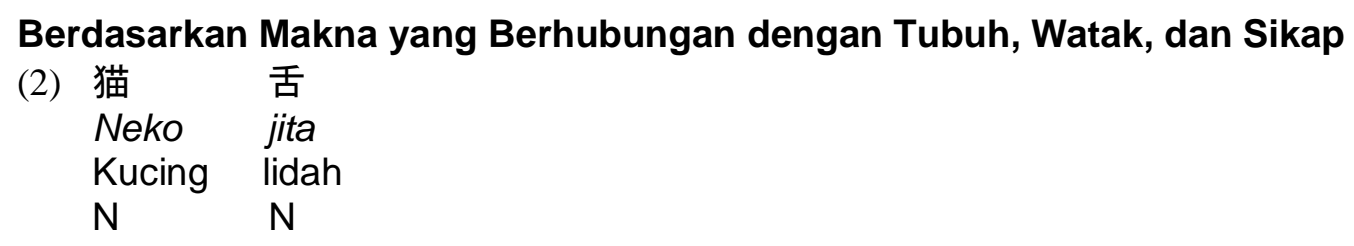

Idiom nekojita berdasarkan pembentuknya terbentuk dari nomina neko 'kucing' dan nomina jita 'lidah' secara leksikal nekojita berarti lidah kucing, namun secara idiomatikal merupakan ungkapan untuk menyebut seseorang yang tidak bisa makan makanan yang panas juga minum minuman yang panas. Contoh dari idiom nekojita adalah sebagai berikut. 私は猫舌ですので、すぐお汁粉を飲むというわけにはいきません。けれども空が鷖って冷た い風が吹いているので、お汁粉は舌に優しい温度まで冷めました。 
Watashi wa nekojita desu no de, sugu oshiruko o nomu to iu wake ni wa ikimasen. Keredomo sora ga kagette tsumetai kaze ga fuite irunode, oshiruko wa shita ni yasashī ondo made samemashita.

'karena saya orang yang tidak pandai makan makanan panas, (saya) tidak bisa langsung memakan sup shiruko yang panas. Tetapi, karena langit yang cerah dengan hembusan angin yang dingin membuat suhu panas sup shiruko melebur dan terasa lembut di lidah.'

(yourei.jp)

Idiom nekojita didasari dari lidah kucing yang sensitif terhadap rasa panas. Idiom nekojita digunakan sebagai ungkapan terhadap orang yang tidak pandai memakan makanan atau minuman panas karena memang kebiasaan mereka yang tidak pandai menggunakan lidah untuk memakan sesuatu yang panas, bukan tidak bisa memakan makanan panas karena faktor genetik, alergi atau mempunyai penyakit tertentu (Nishikawa:87).

\section{Berdasarkan Makna yang Berhubungan dengan Perbuatan, Aksi, dan Aktivitas}

$\begin{array}{lll}\text { (3) 猫 } & \text { に } & \text { 鰹節 } \\ \text { Neko } & n i & \text { Katsuobushi } \\ \text { Kucing } & & \text { Katsuobushi } \\ \text { N } & \text { P } & \text { N }\end{array}$

Idiom neko ni katsuobushi berdasarkan pembentuknya terbentuk dari nomina neko 'kucing', partikel ni, dan nomina katsuobshi 'katsuobushi/makanan awetan yang terbuat dari ikan'. Partikel ni dalam frasa ini berarti 'untuk', sehingga idiom ini secara leksikal memiliki arti 'katsuobushi untuk kucing'. Namun secara idiomatikal neko ni katsuobushi menunjukkan suatu keadaan yang 'waspada atau berbahaya'. Contoh dari idiom neko ni katsuobushi adalah sebagai berikut.

財布をダッシュボードの上において車を離れるなんて、普通に猫に鰹節だな。 Saifu o dasshubōdo no ue ni oite kuruma o hanareru nante, futsū ni neko ni katsuobushi da na.

'menaruh dompet di atas dasbor dan meninggalkan mobil, sudah pasti hal yang berbahaya'

(yourei.jp)

Idiom neko ni katsuobushi yang terdapat dalam contoh kalimat tersebut secara idiomatikal menurut Muneo (1992:348) digunakan untuk menunjukkan situasi yang berbahaya, tidak bisa tenang, dan harus waspada. Karena katsuobushi adalah makanan yang disukai kucing, sehingga jika menaruh katsuobushi di dekat kucing adalah hal berbahaya karena kucing pasti akan memakannya.

\section{Berdasarkan Makna yang Berhubungan dengan Keadaan, Derajat dan Nilai}

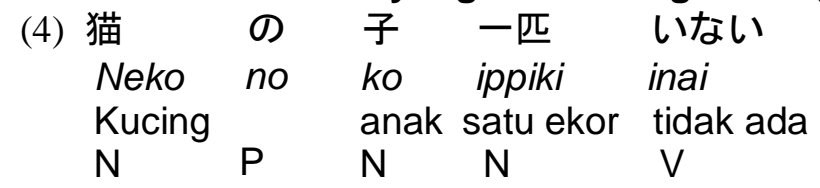

Idiom neko no ko ippiki inai berdasarkan pembentuknya terbentuk dari nomina neko 'kucing', partikel no, ko 'anak', ippiki 'satu ekor', dan inai 'tidak ada'. Sehingga arti idiom ini secara leksikal adalah 'tidak ada satu ekor anak kucing'. Namun menurut Nishikawa (2017:121) secara idiomatikal, neko no ko ippiki inai bermakna sepi atau tidak ada orang sama sekali, saking sepinya sampai kucing satu ekor saja pun tidak ada. Contoh dari idiom neko no ko ippiki inai adalah sebagai berikut.

道に迷ったので、辺りを見回してみたが、猫の子一匹いないので、道を聞くこともできない から困ってしまった。 
Michi ni mayotta no de, atari o mimawashite mita ga, neko no ko ippiki inai no de, michi o kiku koto mo dekinai kara, komatteshimatta.

'(saya) tersesat dan mencoba melihat sekeliling, tapi tenyata sepi dan tidak ada orang sama sekali (saya) jadi tidak bisa menanyakan jalan, (saya) benar-benar dalam masalah.'

(yourei.jp)

Idiom neko no ko ippiki inai berdasarkan contoh kalimat diatas menggambarkan seseorang yang tersesat, dan ketika ingin menanyakan arah jalan, di sekitarnya sepi dan tidak ada orang sama sekali. kucing merupakan binatang yang sering ditemukan dimanamana, seekor kucing betina dapat melahirkan sebanyak 3-4 kali dalam setahun dengan ratarata bayi kucing 2-6 ekor (Hotchner, 2007:67), karena itu jika satu ekor kucing saja tidak ada

akan terasa sangat sepi. sehingga muncullah idiom ini untuk mengungkapkan dan menggambarkan suasana yang sepi dan tidak ada satu orang pun.

$\begin{array}{lll}\text { (5) 猫 } & \text { も } & \text { 食わない } \\ \text { Neko } & \text { mo } & \text { kuwanai } \\ \text { Kucing } & & \text { tidak ingin makan } \\ \mathrm{N} & \mathrm{P} & \mathrm{V}\end{array}$

Idiom neko mo kuwanai berdasarkan pembentuknya terbentuk dari nomina neko 'kucing', partikel mo, dan verba kuwanai 'tidak ingin makan'. Sehingga arti idiom neko mo kuwanai secara leksikal adalah bahkan kucing tidak ingin memakannya. Namun secara idiomatikal merupakan sebuah ungkapan untuk menyebut makanan yang rasanya benarbenar tidak enak. Dapat dilihat dari contoh kalimat sebagai berikut.

\section{写真からは非常に美味しそうな食べ物なんですが、食べてみると猫も食わないほどの味で} す。

Shashin kara wa hijou ni oishisou na tabemono nan desu ga, tabete miru to neko mo kuwanai hodo no aji desu.

'saat lihat dari fotonya sih benar-benar makanan yang terlihat sangat enak, tapi saat mencoba memakannya, rasanya sangat tidak enak.'

(aozora.gr.jp)

Idiom neko mo kuwanai berdasarkan contoh kalimat menggambarkan sebuah makanan yang ketika dari foto terlihat enak, namun saat mencoba memakannya sangat tidak enak. Neko mo kuwanai secara leksikal berarti bahkan kucing tidak memakannya, dan secara idiomatikal bermakna sangat tidak enak. Berdasarkan contoh kalimat tersebut hubungan antara makna leksikal dan idiomatikal dari idiom neko mo kuwanai saling berhubungan, karena jika sebuah makanan tidak terasa enak, kucing pun tidak ingin memakannya.

\section{Simpulan dan Saran}

Kesimpulan dari hasil analisis yang telah dan diperoleh dari laman yourei.jp dan aozora.gr.jp adalah terdapat 21 idiom bahasa Jepang yang terbentuk dari kata neko yang diklasifikasikan berdasarkan klasifikasi idiom menurut Muneo yang terdiri dari 6 idiom yang berhubungan dengan perasaan dan emosi, 4 idiom yang berhubungan dengan tubuh, 7 idiom yang berhubungan dengan perbuatan dan aksi, 4 idiom yang berhubungan dengan keadaan, derajat dan nilai. Namun berdasarkan hasil yang sudah didapat sesuai dengan sumber data, tidak ditemukan idiom yang menyatakan klasifikasi shakai, bunka, seikatsu o arawasu kanyōku atau idiom yang berhubungan dengan masyarakat, budaya, dan kehidupan. Idiom yang menggunakan kata neko secara umum menujukkan makna yang berhubungan dengan manusia, seperti tubuh, perasaan, perbuatan dan keadaan. Idiom seringkali digunakan dalam proses komunikasi masyarakat Jepang, namun penelitian mengenai idiom bahasa Jepang masih harus lebih banyak dilakukan lagi, maka dari itu penulis berharap penelitian ini dapat dijadikan sebagai salah satu referensi untuk penelitian selanjutnya. Penulis menyadari bahwa penelitian ini masih banyak kekurangan, oleh karena 
itu penulis berharap akan lebih banyak lagi penelitian mengenai idiom berunsur hewan, ataupun unsur-unsur lainnya terutama idiom bahasa Jepang yang pengumpulan datanya berasal dari audio visual seperti anime, drama, maupun acara televisi Jepang agar penelitian kanyōku atau idiom bisa lebih mendalam.

\section{Daftar Pustaka}

Chaer, A. 2003. Linguistik Umum. Jakarta: PT Rineka Cipta. 1994. Pengantar Semantik Bahasa Indonesia. Jakarta: PT Rineka Cipta.

Hiroshi, M. \& Kameda, M. 2014. Chuukyuu kara Manabu Nihongo.Tokyo: Kenkyusha.

Hotchner, T. 2007. Cat's Bible. London: Penguin Publishing.

Keraf, G. 2006. Diksi dan Gaya Bahasa. Jakarta: Gramedia Pustaka Utama.

Mahsun. 2007. Metode Penelitian Bahasa. Jakarta: PT Raja Grafindo Persada.

Maynard, M. \& Senko K. M. 2009. 101 Japanese Idioms. Lincolnwood: Passport Books.

Miharu, A. 2002. Yoku Wakaru Goi. Tokyo: ALC Press.

Muneo, I. 1992. Reikai Kanyouku Jiten. Tokyo: Sotakushashuppan.

Kana, N. 2017. Masuku Neko to Neko no Kotowaza \& Kanyouku. Tokyo: Shufunotomo.

Kurumi, I. 2004. Repeat. Tokyo: Bungeishunju.

Nuryantiningsih, F. 2018. Semantik Bahasa Indonesia. Purwokerto: Universitas Jenderal Soedirman.

Soepardjo, D. 2012. Linguistik Jepang. Surabaya: Bintang.

Sudaryanto. 2015. Metode dan Aneka Teknik Analisis Bahasa. Yogyakarta: Sanata Dharma University Press.

Suhardi. 2017. Dasar-Dasar IImu Semantik. Yogyakarta: Ar-Ruzz Media.

Sutedi, D. 2011. Dasar-Dasar Lingustik Bahasa Jepang. Bandung: Humaniora.

Tjandra, S.N. 2015. Semantik Jepang. Jakarta: Binus Media \& Publishing. 